doses of four or five grains daily, learn that the continued daily use of five or ten times as much are essential to obtaining its peculiar effects, and he will suspect that in our classes of disorders, medical agents must be given with a bold hand, as they are, and should be under a vigilant eye.

The administration of diffusible stimuli in the affection which has occupied the preceding pages, must be thus governed.

At the next meeting of our association, I trust that the experience of so many of us, in such wide fields of observation, may enable the many deficiencies, incident to this topic, to be more or less accurately filled.

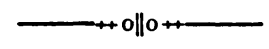

ARTICLE II.

\title{
The Relation between Phrenology and Insanity.
}

Br H. A. BUTTOLPH, M. D.,

Superintendent of the State Lunatic Asylum, Trenton, Newo Jersey.

[The following article was read before the Association of Medical Superintendents of American Institutions for the Insane, at their session at Utica in May last, and was not intended for pablication. The writer not having timo to revise it, -on that account rather reluctantly yields to our request, to insert it in the Journal.-Editor Journal.]

For the purposes of this inquiry, it will be assumed that phrenology is the true science of mind, and therefore, that it bears a direct and important relation to insanity.

This science teaches that the mind is a perfect whole, but made up of many parts or faculties ; that these faculties are primitive peculiar powers, that they differ in strength, relative and absolute in different persons, and finally, that they depend upon the brain for their manifestation. Phrenology, then, is the science of the beal- 
thy functions of the brain, or the physiology of that organ.

Insanity is the term used to signify the perverted or deranged state of the mental functions, and is embraced in the pathology of the same organ.

Phrenology bears the same relation to insanity, that physiology does to pathology.

To give a brief outline of the relations between this science and insanity; and to point out in a general way its practical bearings upon the subject, is all that is now contemplated.

For a full discussion of the subject, a volume would be required; and also the possession and exercise of enlarged powers of mental analysis and discrimination, and minute knowedge of the structure and functions of the brain, and nervous system generally.

The truth of phrenology being admitted, no proof or argument is required to establish the importance of a correct knowledge and application of its principles by those engaged in conducting the moral treatment of the insane, and it may be added with equal propriety, by all those concerned in the guidance and training of the human faculties; whether acting in the capacity of parents, guardians, mental and moral, or even religious instructors :-indeed, the knowledge of the true science of mind, is indispensable to the attainment of the greatest success and highest enjoyment, in any and all the departments of life. That persons have succeeded to a certain extent in many of the stations alluded to, without a knowledge of its principles, and perhaps while even opposing and ridiculing the science, is true ; and yet this fact forms no real objection to the ground here taken ; for if without this knowledge good has resulted, how much greater good would have been secured, and how much farther advanced would have been the race of man in the attainments of science, literature and art : 
in civil government, and in the moral and religious sentiments, if the diffi rout classes of hunan firculties had always reccived the training lest adapted for their full developement, and harmonious cxercisc.

But in proceed in stating the relations of the science to the suliject in question.

For convenience of description its bearings will be considered in reference to the prevention, diagnosis, prognosis and trealunent of mental disensc.

Prevention of Ixsanitr--To this branch of the inquiry aloure, might be given the space ailotted to the entire essily, so mumerous, voriod and inportant are the moans siggested hy phrennloge, fire preventing this discass. The first and indispensible condition to mental soundness, is the possession of a well proportioned healthy brain, and in secure it, phremolngy stggests that due attention he paid to the linws of hereditary desecut, and 1o those of heralth geucrally. For pricticial direcions for sccuring the desired results, through the application of phrenological and physiological latws, reference is macie to the various systcmatic treatises relating to these sciences.

Next in importance in the possession of a well formed and heiblihy bratin, is the educittion, or training of the ficculties. In this is cmbraced unt only such instruction as is necrssary in acquiring a knowledge of the various arts and sciences, as painting, sculpture, langmige, music, mahlicmaltics, che., hut also such prolonged and systcmallic use of the firculies, as is cilleulated to excite and strenglien the wiak, calm and repress the over-strong, and confirm each class, and the imlividuils of the various classes, in the tendency to concerted and barmonious action. Finally, a direct acepuaintance with the principles of phrenolugy, and a cordial and implicit obedicuce (1) ilucir dictate's, are also indispensable to the full attainment of its proffered securities against disease. 
A knowledge of this science, gives to every reflecting man an intimate knowledge of his own ficulties, hy which means he is forewarned of danger and avoids the circumstances likely to disturb the equilibrium of his powers :-or if, perchance, he is occasionally surrounded by adverse influences, from which there can be no escape, he is thereby better prepared to submit to their effects; and if thoroughly inibued with the principles of the science, will do so, evincing the calmness of the philosopher and the patience of the christian. Can anything be conceived of loctter adapted to prevent insanity, than the babitual exercise of ficculties thus trained for action or for christian submission under trial?

Diagnosis of Insanitr.-The correct diagnosis of this, as of other diseases, is often a matter of equal ditficulty and importance. Whether the acts of a man are considered in relerence to his social, moral or legal responsibilities, as connected with othors, or simply in reference to the necessity of medical and moral treatment, for his own welfire and safety, the question of diagnosis is important. Here, again, phrenology comes to our airl, and by revealing il correct systern of mental philusophy, grently assisis us in forming correct views of the conduct and motives of others, both in healih and diseasc. When mental derangement results from obvious and well known causes, and is exhibited by a sudden and striking chinge in the intellectual character of the individual, no difficulty is experienced in its diagnosis. Where, however, it arises from very slight disease of the brain, induced by either physical, inental, or moral causes, separately or combined; the departure from the healthy mental standard of the individual, consisting only in a slightly increased or lessened acuteness of the intellect, with occasionil faint delusions in regard to external relations and objects, coupled with a disturbed state of the moral, social, or animal feelings; inducing 
timidity, suspicions, jealousy or revenge, according to the natural predominance of these feelings, or the extension of the discast of the brain, so as to embrace the organs of these fitculties; the cliagnosis is ofien diffcult, and if, as it frequently occurs, the question of the responsibility of the subject, for the commission of crime is raised, the correct diagnosis becomes a matter of great importance; involving as it may, the liberty, civil rights, or even the life of the individuil.

Masked disease of this kiud often exists for months and years, unsuspected by the friends of the parties, or oilier persons, until some sudilen, though perhaps long premeditited act of fraud, of suicide, or of homicide, reveals the truth.

In other instances, disease may pritnarily affect the organs of the feelings, prisoning their fountiains, exciting, depressing or perverting them firom their office and ministry in the mential group; and in the end, resulting as did the former, in some sud and unlooked for catastrophe.

I need not cite examples in illustrition of the cases here described; the records of hospitals for the insane, and courts of justice, and injustice, ton, are filled with them, and it maly be added, with shame to the jurisprudence of every country, that these persons are often made the victims of their misfortune, as diseased subjects, in the dungeon and on the scaffold.

But why these mistakes in jurisprudence, - why these immolations of individual cases of insanity, which are only speciunens of large classes, in every public establishuncht for their cure? The answer, undeniably, is, that judges, and jurors, and lawyers, persist in shutting their eyes, in stopping their ears, and in hardening their hearts, against the obvious teachings, and the oft-repeated demonstrations of phrenology.

The bare mention of the fundamental principles of the science, that the mind is composed of a plurality of fac- 
ultics, depending upon the brain for their manifestations; that through disease of this organ, the social, inorial and animal, no less than the intellectual powcrs, are subject to derangement and impaired responsilility, is sufficient to solve the whole mystery altached to " inoral ins:mity." With these facts in view, the unmeaning trumpery of the courts, about funding a test of montal somducss in the state of the memory, the reason or the conscience, vanishes like darkness before the light of day; leading us devoutly to wish that the dugmas of obsolete systems of mental science, which still mystify and mislead judi. cial authorities, in regard to the diagnosis of insinnity, cotild be consigned to oblivion, as sunmarily and as perfectly, in the practice of the courts, as thoy hate bero in theory, by their phrenological judgr's.

Prog.xosis of Insanity. - The relations between phrenology and the proginsis of insauity, is also worlly of allention; for allhough the result of disease in the brain caunot alwiys be foreto!d by the aid of any and all the means within our reach, yet a full unilerstanding of the nature and oljects of the prim try ficcultics, and of their mutual and reciprocal influence and dependence upon each other, in diseasc as in bealii, will aid the physician in adapting the moral treatment, to the inemtal constitution of each patient, thereby ellabling him, in anany cases, to anticipate the final result.

Treatment of Insanity.-The treatment of insanity is properly divided into physical and mental, or medical and moral. 'To the firmer belong the use of all physical agents, as medicinc, baths, cliet, clc., ctc., which should be applied in accordinnce with the patho. logical indications of cach case. To the moral treatment of the disnder, belong the use of mental and moral agencies, aurl that the insine mily derive the full benefit of their influence, liby should be applied as nearly in accordance with the principles of mental sci- 
ence, ns the cxisting derangement of the faculties will permit.

That there exists an iminate and important relation between plirenology and the mental and moral treatment of the iusiune, is obvinus from the theory of the ficultics; and the comparative results of ancient and merlerm praclice.

Under the old system of mential philosophy, the mind was gencrally regarded as a unit in its constiution, and as ethereal in its essence. It was believed 10 exist in each person as an inumalerial rmalnation form the Creator, aud that aluhough slighty connectod with some point of the bod!e, brain or nerves, yet that it was quite too dignified and refined in its character and offices, to be subject to physice:l laws. During the previalence of these views, all chinges in the mental aud moral stite of in. dividuals were accounted for hy supposing that the onind was deternined in its volitions; by the intluence of good and bad spirits: the charalcter of the ageut being inferred, fion the conduct of the sul,ject.

At this time the insine were considered as being possessed with devils, and of course, exorcisin resonted to fior their rolief. After the agres of wonder passed by, improved views of physical science, and with them of moutal philosophy, gradually arose, each era heing morked by progressive advancement in the treatment of physical and mental disurders. The iusane, however, were still treated with neglect, with ridiculs and with violent abuse, pursued oficn to the death of the hapless victions.

The carly attempts at medical treatment consisted mainly in the "prescription of iujurinus or useless drugs, given without reie: ance to the peculiarities in the physicial arol mental symptoms." Finally, asylums, or rather " medical prisons," were provided for their sate custody, and in which they were often immured for life, 
subject to the mockery, abuse and stripes of inhuman kecepers; without any atlempt at ratioual tratment, willout employenent or amusements, and with only gloomy walls and galling chains for companions. In this state of wreteheduess and degradiation they were abandoned by friends, who desired the knowiedge of their connecion with them extinguished.

In inodern times inprovel views of the medical and moral treatment of the insane have kept pitce with the advanciug state of plysicial and mental science : but although gratat ameliorations in the condition and manageoneut of this class hat been effected prior to the introduction of the phrenological philosophy of mind, by the enlightoned and benevolent Pinel and others, yet, to the prevalence of this sjstem are the insine mainly indebted for the well detined atud philosophical views of mental and moral treatment unow in vogue. That some have adopted the maxims of phrebology wilhout admiting, or perchance even knowing their obligation to the science, may occiasionally be as true of physicians, in treating insanity, as of professors and divmes, in teaching science and theolngy : their silence however, in regited to the merits of the former, or even their opposition to its truth, may not be valid proof against its relations to the latter subject. "By revealing the nature, number and origin of the human ficculues, the contitions of their operations, their mutual influence, their modes of acting, and the natural liaws by which their manifestations are regulatcd," phrenology has assisted to elucidate and more fully to estiblish the correct systern of moral treatment of the insanc, than any and all former systems of mental science. In the treatment of insanity, it teaches that the disordered facculiy or faculties when depending upon recent and acute disease of the brain, should remain at rest, or as nearly approximating this state as possible. To this end, treatment in an asylum or bospital is gen- 
erally preferable to private : the deranged faculties being less sulject to agitation from outward occurrences, and morc readily yield to nccessary restraints imposed by strangers, in a public institution, than by friesds, in their nown dwellings, or when at lurge.

When, however, the faculties become torpid and wenk from long continued overaction, or from want of mental stimuli, it may, and ofien does become an object of attellion, to arnuse them to greater activity, hy supplying such pinysical and mentil exercise and amuscments, as are adapted to secure this effect.

In this last particulinr, the variety of means brought to bear in interesting and improving the sound faculties, or those capable of being exercised with advantage to the unsound, does the superiority of modern treatment mainly consi't.

In carrying out these views in hospital practice, in such a manner as 10 secure the best curative resul's, the exercisc of discriminating and well disciplined faculies on the part of the physician are required, aided by weell adapted architrctural arrangements for classificantion and other purposes; together with the liberal expenditure of moncy, in supplying facilities lior engiging the attention of each and all the perceptive, for occupying, interesting and improving the intellectual ficulties, and fir encouraging, tranquilizing chrering, and changing the perverted, social, moral and religious sentiments, and the animal propensitir's.

Such $i$ : a very brief and general outline of the relations between phrenology and insanity.

As before mentioned, a voluine would be required to describe, in detail, its highly interesting and theoretical and important practical $r$ lations to the prevention, diagnosis, prognosis and treatment of this disense.

In conclusion, I nay be permitted to state, that phrenology, by supplying a correct basis tor a system of 
mental philnsophy, has alreaciy achieved important results in jurisprudence and insinity; and still firrber, to express the hope and belief, that it is vet destiurd to atecomplish the intellectual, social, political, motai and religious renovation of the race of man.

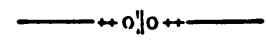

\section{AR'TICLE I!I.}

On the importunce of rstr:blishing separale Institutions for the :Iifferent sreses of the linsune: lo, G. H. White, M. I)., of the Privalle Institution for Iusane Fon iles, Huclson, $\mathbf{N}$. Y.

[Reind before the Association of Supcrintendents of American Institutious fin the Insunc, Muny 2!, $\cdot$, 1S49.]

To itre:ommolate the insalne we wa:t and need unore Asyluns in cerery stinte in the Union.

But conparallicely fiew call unw enjoy lhe benefits of the institutions alreidly establisherl. The means and edority of our people: are alsumdinu for the ultimate provision of Asylums for all. 'The returns fien cerer part of the country show how inadequate are die institutions alreacly established to meet the wants of the insane populiution.

As yet arrangements have only been made in this country fir bohl sexes in the same instilution. The question now arises wheller the present plan cannot be improved by estiblishing seprivure as;/ / mms for males and femalcs? 'lhe insane are well maniged in oar institutions as they are alrcaly orginnized, and many objections maly be advanced against any change in the original plan, I an well aware, with some pliussibility.

But it appears to me that lhe spirit of the age requires a deviation from the course commonly pursued. If a school is establisbed, the separation of the sexes is car- 